\title{
Matrix metalloproteinases-9 and tissue inhibitor of matrix metalloproteinases- 1 in sarcoidosis patients
}

\author{
Jasmina Ivanišević ${ }^{* *}$, Aleksandra Stefanović ${ }^{1}$, \\ Jelena Kotur Stevuljević ${ }^{1}$, Zorana Jelić Ivanović ${ }^{1}$, Slavica Spasić ${ }^{1}$, \\ Jelica Videnović Ivanov², Violeta Vučinić Mihailović ${ }^{2}$ \\ ${ }^{1}$ University of Belgrade - Faculty of Pharmacy, Department of Medical Biochemistry, \\ Vojvode Stepe 450, 11221 Belgrade, Serbia \\ ${ }^{2}$ Clinic for Pulmonary Diseases, Clinical Centre of Serbia, Koste Todorovića 26, \\ 11129 Belgrade, Serbia \\ *Corresponding author: Jasmina Ivanišević, Tel: +381 113951 265, Fax: +381 113972 840, \\ e-mail: jasminai@pharmacy.bg.ac.rs
}

\begin{abstract}
Summary
Matrix metaloproteinases (MMPs) and their specific inhibitors - tissue inhibitors of matrix metalloproteinases (TIMPs) play an important role in pulmonary extracellular matrix destruction. Sarcoidosis is an inflammatory disease affecting multiple organs. It has been reported that MMP-9 and TIMP-1 levels were increased in bronchoalveolar lavage fluid and induced sputum of sarcoidosis patients. The aim of our study was to evaluate MMP-9, TIMP-1 and MMP-9/TIMP-1 complex concentrations and MMP-9/TIMP-1 ratio in sarcoidosis patients, their relationship with inflammatory markers and their ability do predict the existence of disease. We included 101 sarcoidosis patients and 50 healthy subjects. Serum samples were analyzed. Besides routine biochemical parameters, high-sensitive C-reactive protein (hsCRP), serum amyloid A (SAA), MMP-9, TIMP-1 and MMP-9/TIMP-1 complex concentrations were measured. MMP-9 $(\mathrm{P}<0.05)$, hsCRP, SAA and TIMP-1 $(\mathrm{P}<0.001)$ concentrations were significantly increased in patients whereas MMP-9/TIMP-1 complex was higher in patients, but with marginal significance. In sarcoidosis, TIMP-1 correlated significantly positively with inflammatory parameters $(\mathrm{P}<0.05)$. Uni-variate analysis showed that MMP-9, TIMP-1, hsCRP and SAA had the ability to predict the existence of sarcoidosis. In the model consisted of MMP9, TIMP-1, hsCRP and SAA, only SAA remained significant predictor of disease $(\mathrm{P}<0.01)$. Results showed the significance of MMP-9 and TIMP-1 in sarcoidosis.
\end{abstract}

Keywords: sarcoidosis; matrix metalloproteinase-9, tissue inhibitor of matrix metalloproteinase-1, inflammation 


\section{Introduction}

Normal lung functions are supported by extracellular matrix (ECM). Abnormal remodelling and destruction of ECM occurs in many pulmonary diseases. It has been described that matrix metaloproteinases (MMPs), a family of zinc and calcium dependent endopeptidases (1) and their specific inhibitors - tissue inhibitors of matrix metalloproteinases (TIMPs) play an important role in pulmonary ECM destruction (1, 2). TIMPs bind MMPs in a 1:1 manner to prevent their enzymatic activity (3). The expression of both MMPs and TIMPs is regulated by exogenous stimuli, cytokines, growth factors and cell-cell contact (2).

Sarcoidosis is an inflammatory disease affecting multiple organs primarily lungs with diverse clinical course. Extensive ECM remodelling reported in these patients occurs as a consequence of granuloma formation common to all disease manifestations (2). Henry et al (4) and Fireman et al (5) found that MMP-9 levels were increased in bronchoalveolar lavage (BAL) fluid and induced sputum of sarcoidosis patients. Shimada et al (6) demonstrated increased TIMP-1 concentration in BAL fluid that was associated with reduced pulmonary function in patients with sarcoidosis. In the study (5), TIMP-1 was increased in sputum of sarcoidosis patients, but with marginal significance. It is estimated that cellular source of MMP-9 and TIMP-1 may primarily be multinucleate giant cells localized in sarcoid granuloma, but also macrophages and epithelioid cells (7).

It has been considered that MMP-9/TIMP-1 complex represents the functionality of antiproteases system. Increased levels of MMP-9 bound to TIMP-1 are usually followed by increased TIMP-1 concentrations and indicate greater efficiency of TIMP-1 in neutralizing MMP-9 (8). MMP-9/TIMP-1 complex concentrations have been documented in patients with neutrophilic and eosionophilic asthma (8) and in chronic obstructive pulmonary disease (COPD) (9). Neutrophilic asthma having higher TIMP-1 concentration than eosinophilic asthma was also characterized by higher MMP-9/TIMP1 complex (8). The study on the patients with COPD reported increased levels of MMP-9/TIMP-1 complex in exacerbation state of disease when compared with stable state or control subjects. However, to our knowledge, there are still no data describing MMP-9/TIMP-1 complex in sarcoidosis.

MMP-9/TIMP-1 ratio indicates a shift in the balance between the enzyme and its inhibitor in favour of MMP-9. It means that ratio would be increased in the state of increased proteases activity (4). Previous studies $(4,5)$ showed increased levels of this parameter in sarcoidosis patients when compared with controls although significant difference was not found in the study (4).

The aim of our study was to evaluate MMP-9, TIMP-1 and MMP-9/TIMP-1 complex concentrations and MMP-9/TIMP-1 ratio in sarcoidosis patients, their 
relationship with inflammatory markers and their ability do predict the existence of disease.

\section{Materials and methods}

\section{Subjects}

In this study, we included 101 sarcoidosis patients from the Clinic for Pulmonary Diseases and Tuberculosis, Clinical Centre of Serbia, Belgrade. The diagnosis was established by clinical, radiological and histological findings (10). Patients underwent biopsy analysis that confirmed noncaseating epithelioid granulomatous inflammation in the appropriate organ/tissue. Other non-infectious and infectious causes of granulomas had been excluded. The exclusion criteria for the patients were the presence of cardiovascular disease, pulmonary (any other pulmonary disease except sarcoidosis), neurological, renal, hepatic, endocrine or malignant disease. Among patients, 84 were prescribed prednisolone, 14 were prescribed prednisolone together with methotrexate and 3 were received only methotrexate. Low daily dose of prednisolone was applied (median: $10 \mathrm{mg}$; interquartile range: 5-10 mg) whereas methotrexate was applied weekly (median: $5 \mathrm{mg}$; interquartile range: 5-10 $\mathrm{mg}$ ). We also included 50 healthy subjects who were at their regular medical check-up at the local health center and accepted the participation in this study. The inclusion criteria for controls were the absence of any pulmonary, gastrointestinal, hepatic, renal, cardiovascular, malignant or endocrine disease. The study was planned according to the ethical guidelines stated in the Helsinki declaration. Written informed consent was obtained from all subjects prior to study entry. The research was approved by the institutional committee (Ethics Board) of Clinical Centre of Serbia.

\section{Sample collection}

After a 12-hour fasting period, venous blood samples were collected into serum sample tubes and then centrifuged $\left(1500 \mathrm{xg}, 10 \mathrm{~min}\right.$ at $\left.4^{0} \mathrm{C}\right)$ to obtain serum. Samples were aliquoted and stored at $-80^{\circ} \mathrm{C}$. Aliquots were thawed immediately before analyses.

\section{Biochemical parameters}

Concentration of serum glucose, total protein, albumin, total calcium, urea, creatinine and uric acid as well as activity of alkaline phosphatase were assayed by routine laboratory methods (ILAB 300+analyzer, Instrumentation Laboratory, Milan, Italy). The latex-enhanced immunoturbidimetry method (Quantex hsCRP kit, BIOKIT, Barcelona, Spain) was used to measure the concentration of high-sensitive C-reactive protein (hsCRP) on an ILAB 600 analyzer. ACE was determined by commercially available colorimetric method (Fujirebio Diagnostics Inc.) with p-hydroxybenzoylglycyl-L-hystidyl-L-leucine as a substrate. The concentration of serum amyloid A (SAA) was determined by a commercially-available two-site enzyme linked 
immunosorbent assay (ELISA) kit (Immunology Consultants Laboratory, Portland, OR, USA).

MMP-9, TIMP-1 and MMP-9/TIMP-1 complex concentrations were measured by commercially available enzyme-linked immunosorbent assay (ELISA) kits (Research and Diagnostics Systems, Minneapolis, MN, USA). The intra- and inter-assay coefficients of variation (CV) were as follows: $1.9 \%$ and $7.8 \%$ for MMP-9, 3.9\% and $3.9 \%$ for TIMP-1, and 2.6\% and 4.5\% for MMP-9/TIMP-1 complex. MMP-9/TIMP-1 ratio was calculated.

\section{Statistical analysis}

To describe the data, we used means \pm standard deviation for normally-distributed data, geometric means and 95\% confidence intervals for log-transformed normallydistributed data, median and interquartile range for non-normally distributed data and absolute frequencies for categorical variables. The normality of distribution of parameters was assessed using the Kolmogorov Smirnov test. Continuous variables having normal or log-normal distribution were compared using Student's t-test. The Mann Whitney test was used for comparisons of non-normally-distributed data. Differences between categorical variables were tested with Chi-square test for contingency tables. Spearman's correlation analysis was employed to determine possible correlations between examined parameters. The ability of parameters to predict disease was estimated using binary logistic regression analysis. All statistical analyses were performed using MS Excel, PASW Statistics Version 18.0 and MedCalc (version 11.4 Software, Belgium) software. The 0.05 probability level was considered significant in all statistical tests.

\section{Results}

Demographic and biochemical parameters of sarcoidosis patients and control group are given in Table 1. Patients and controls were matched according to age and gender. The concentrations of glucose, urea and creatinine were significantly lower whereas the concentrations of total proteins and albumin were significantly higher in patients group when compared to controls. HsCRP and SAA were significantly increased in patients and ACE activity was above borderline value of reference interval. (Table I) 
Table I Basic biochemical characteristics and inflammatory parameters of sarcoidosis patients and control group

\begin{tabular}{|c|c|c|c|}
\hline Parameter & $\begin{array}{l}\text { Controls } \\
(\mathrm{N}=50)\end{array}$ & $\begin{array}{l}\text { Sarcoidosis } \\
(\mathrm{N}=101)\end{array}$ & $\mathrm{P}^{\mathrm{c}}$ \\
\hline Age (years) & $47.3 \pm 9.4$ & $51.0 \pm 10.9$ & 0.057 \\
\hline Gender (m/f) & $20 / 30$ & $32 / 69$ & $0.406^{d}$ \\
\hline Glucose $(\mathrm{mmol} / \mathrm{L})$ & b5.2 (4.8-5.5) & $4.9(4.5-5.6)$ & 0.031 \\
\hline Urea (mmol/L) & $6.21 \pm 1.41$ & $5.56 \pm 1.56$ & 0.015 \\
\hline Creatinine $(\mu \mathrm{mol} / \mathrm{L})$ & $86.7 \pm 12.0$ & $81.5 \pm 13.4$ & 0.030 \\
\hline Uric acid $(\mu \mathrm{mol} / \mathrm{L})$ & $344 \pm 93$ & $291 \pm 86$ & $<0.001$ \\
\hline Total proteins $(\mathrm{g} / \mathrm{L})$ & $69.1 \pm 5.2$ & $72.3 \pm 5.1$ & $<0.001$ \\
\hline Albumin (g/L) & $35.1 \pm 1.5$ & $43.2 \pm 3.0$ & $<0.001$ \\
\hline Calcium (mmol/L) & / & $2.35 \pm 0.10$ & / \\
\hline $\begin{array}{l}\text { Alkaline phosphatase } \\
\text { (U/L) }\end{array}$ & / & $73.9 \pm 23.5$ & l \\
\hline hsCRP (mg/L) & ${ }^{\mathrm{a}} 0.97(0.75-1.24)$ & $2.05(1.63-2.56)$ & $<0.001$ \\
\hline $\mathrm{ACE}(\mathrm{U} / \mathrm{L})$ & / & b53.0 (42.0-67.0) & l \\
\hline $\mathrm{SAA}(\mu \mathrm{g} / \mathrm{mL})$ & a2.64 (1.96-3.55) & $9.94(7.57-13.05)$ & $<0.001$ \\
\hline
\end{tabular}

a-geometric mean and $95 \%$ confidence interval,

$\mathrm{b}-$ median and interquartile range

c - Student t-test, $\mathrm{d}$ - Chi square test

Results obtained for protease/antiprotease system are presented in Table 2. The concentrations of MMP-9 and TIMP-1 were significantly higher in sarcoidosis patients when compared with those obtained for controls. MMP-9/TIMP-1 complex was higher in patients, but with marginal significance. The ratio of MMP-9/TIMP-1 was lower in patients although without significant difference. (Table II) 
Table II MMP-9, TIMP-1 and MMP-9/TIMP-1 complex concentrations and ratio MMP-9/TIMP-1 in sarcoidosis patients and controls

\begin{tabular}{lccc}
\hline \multicolumn{1}{c}{ Parameter } & Controls & Sarcoidosis & $\mathrm{P}^{\mathrm{b}}$ \\
\hline MMP-9 $(\mathrm{ng} / \mathrm{mL})$ & ${ }^{\mathrm{a}} 131.2(109.5-152.0)$ & $172.3(152.3-195.3)$ & 0.010 \\
TIMP-1 (ng/mL) & $143.0 \pm 49.3$ & $229.4 \pm 104.3$ & $<0.001$ \\
$\begin{array}{l}\text { MMP-9/TIMP-1 } \\
\text { complex (ng/mL) }\end{array}$ & ${ }^{\mathrm{a}} 1.14(0.74-1.75)$ & $1.80(1.39-2.34)$ & 0.062 \\
$\begin{array}{l}\text { MMP-9/TIMP-1 } \\
\text { ratio }\end{array}$ & ${ }^{\mathrm{a}} 0.974(0.817-1.160)$ & $0.829(0.733-0.938)$ & 0.140 \\
\hline
\end{tabular}

a - geometric mean and $95 \%$ confidence interval,

$\mathrm{b}$ - Student t-test

We performed Spearman's correlation analysis to test associations of MMP-9, TIMP-1, MMP-9/TIMP-1 complex and MMP-9/TIMP-1 ratio with ACE, hsCRP and SAA in sarcoidosis and controls. In sarcoidosis, TIMP-1 correlated significantly positively with all mentioned inflammatory parameters and MMP-9/TIMP-1 ratio was in inverse association with ACE. These results are given in Table 3. In control group, no significant associations were found between protease/antiprotease and inflammatory markers. (Table III) 
Table III Association ofMMP-9, TIMP-1 and MMP-9/TIMP-1 complex concentrations and ratio MMP-9/TIMP-1 with inflammatory parameters in sarcoidosis patients

\begin{tabular}{lccc}
\hline Parameter $^{\mathrm{a}}$ & $\mathrm{ACE}(\mathrm{U} / \mathrm{L})$ & $\mathrm{hsCRP}(\mathrm{mg} / \mathrm{L})$ & $\mathrm{SAA}(\mu \mathrm{g} / \mathrm{mL})$ \\
\hline MMP-9 $(\mathrm{ng} / \mathrm{mL})$ & -0.001 & 0.118 & 0.046 \\
TIMP-1 (ng/mL) & $0.452^{* *}$ & $0.216^{*}$ & $0.330^{*}$ \\
$\begin{array}{l}\text { MMP-9/TIMP-1 } \\
\text { complex (ng/mL) }\end{array}$ & -0.034 & 0.066 & 0.088 \\
MMP-9/TIMP-1 ratio & $-0.248^{*}$ & 0.083 & -0.099 \\
\hline
\end{tabular}

$\mathrm{a}-$ Spearman correlation coefficient, ${ }^{*} \mathrm{P}<0.05 ; * * \mathrm{P}<0.01$

In order to determine whether the measurement of protease/antiprotease and inflammatory parameters had the potential to predict disease, we used binary logistic regression analysis. In the uni-variate analysis, MMP-9, TIMP-1, hsCRP and SAA showed the ability to predict the existence of sarcoidosis. These results are presented in Table IV. However, when each of these parameters (MMP-9, TIMP-1, hsCRP and SAA) adjusted for the parameters presented in Table IV, only SAA remained significant predictor of disease $(\mathrm{OR}=4.599 ; 95 \% \mathrm{CI}=1.150-18.392 ; \mathrm{P}=0.031)$. 
Table IV Binary logistic regression analysis of risk potentials for protease/antiprotease system and inflammatory markers

\begin{tabular}{lccc}
\hline Parameter & OR & $95 \% \mathrm{CI}$ & $\mathrm{P}$ \\
\hline MMP-9 (ng/mL) & 1.003 & $1.000-1.007$ & 0.041 \\
TIMP-1 (ng/mL) & 1.015 & $1.009-1.022$ & 0.000 \\
MMP-9/TIMP-1 & 1.060 & $0.971-1.158$ & 0.195 \\
complex (ng/mL) & 0.912 & $0.664-1.252$ & 0.568 \\
$\begin{array}{l}\text { MMP-9/TIMP-1 } \\
\text { ratio }\end{array}$ & 1.523 & $1.185-1.957$ & 0.001 \\
hsCRP (mg/L) & 1.252 & $1.066-1.469$ & 0.006 \\
SAA $(\mu \mathrm{g} / \mathrm{mL})$ & & & \\
\hline
\end{tabular}

The dependent variable was disease status sarcoidosis (1) comparing to control (0)

\section{Discussion}

In our current study, we found that concentrations of hsCRP, SAA (Table I), MMP-9 and TIMP-1 (Table II) were significantly higher in sarcoidosis when compared with controls. TIMP-1 correlated significantly with all mentioned inflammatory markers (Table III). HsCRP, SAA, MMP-9 and TIMP-1 showed the potential to predict sarcoidosis (Table IV), but only SAA in multivariate analysis remained significant predictor of disease.

As sarcoidosis is an inflammatory disease, it has been expected to observe increased values of hsCRP, $\operatorname{ACE}(11,12)$ and SAA compared to controls $(13,14)$ and our results were in agreement with these findings (Table I). Increased concentrations of SAA may be a consequence of either increased production of proinflammatory cytokines that stimulate hepatic production of SAA (11) or activated cells in granulomas that also produce SAA (15).

Our result of significantly increased concentration of MMP-9 in sarcoidosis comparing to controls (Table II) may be due to the inflammatory processes that are associated with protease/antiprotease imbalance (2). It has been documented that multinucleate giant cells and macrophages found in granulomas $(2,4,7)$ and epithelial cells (2) are the sources of MMP-9 which may initiate ECM breakdown and 
remodeling. Henry et al (4) and Fireman et al (5) found that MMP-9 levels were increased in BAL fluid and induced sputum of sarcoidosis patients. MMP expression may be upregulated by increased production of proinflammatory cytokines (2). Additionally, it has been reported that SAA may induce MMP production in synovial fibroblasts of patients with rheumathoid arthritis $(16,17)$ and our finding of increased MMP-9 could be also supported by increase in SAA concentration.

We found significantly higher levels of TIMP-1 in sarcoidosis than in controls (Table II) and TIMP-1 showed significant positive associations with inflammatory parameters (Table III). In the study of Fireman et al (5), it was shown that TIMP-1 was higher in sarcoidosis than in controls, but with marginal significance. Nevertheless, Shimada et al (6) observed significantly increased concentrations of TIMP-1 in sarcoidosis patients with stage 2 when compared with patients in stage 1 . This suggests that more pronounced inflammation occuring in stage 2 may contribute to higher levels of TIMP-1. Similar result of highest TIMP-1 concentration in sarcoidosis patients with stage 3 when compared with those in stage 1 and 2 (4) may additionally confirm the influence of inflammation on ECM proteins. The sources of TIMP-1 have been considered to be lymphocytes (18) and macrophages (19). Previous report (6) revealed that MMP-9 concentration and MMP-9/TIMP-1 ratio were not altered significantly by the stage of disease indicating that TIMP-1 may be more sensitive to inflammation than MMP-9. In this study, it was also shown that only TIMP-1 correlated significantly with vital capacity of the lung. Capacity of the lung can be infuenced by inflammation (6) and this could be an explanation for significant correlations obtained only between TIMP-1 and inflammatory parameters in our study. However, Piotrowski et al (20) found no significant correlations between neither MMP-9 nor TIMP-1 with lung function parameters.

According to our knowledge, the current study was the first to demonstrate the concentrations of MMP-9/TIMP-1 complex in sarcoidosis which was higher than in controls, but with marginal significance (Table II). On the other hand, MMP-9/TIMP-1 ratio was lower in patients than in controls with no significance (Table II). The complex is considered to represent functionality of antiproteases (8) whereas the ratio shows the balance between protease and antiprotease in favour of protease activity (4). Increased levels of MMP-9 bound to TIMP-1 are usually followed by increased TIMP-1 concentrations and indicate greater efficiency of TIMP-1 in neutralizing MMP-9 (8). The same authors (8) demonstrated that neutrophilic asthma having higher TIMP-1 concentration than eosinophilic asthma was also characterized by higher MMP-9/TIMP1 complex. Our patients also had higher TIMP-1 concentration than controls with higher MMP-9/TIMP-1 complex. Previous study (9) on COPD patients also described increased levels of MMP-9/TIMP-1 complex in exacerbation state of disease when compared with stable state or control subjects. Nevertheless, our result of unsignificant 
difference of MMP-9/TIMP-1 ratio in sarcoidosis was in accordance with the result obtained in the study of Henry and coworkers (4) where MMP-9/TIMP-1 ratios in sarcoidosis patients having less severe stages of disease did not differ significantly from healthy subjects.

We found that MMP-9 and TIMP-1 as well as hsCRP and SAA in univariate binary logistic analysis were able to predict sarcoidosis (Table IV). In the model consisted of variables listed in Table IV, it was shown that only SAA was the marker which significantly predict disease. The result showed that although MMP-9 and TIMP1 were important in disease prediction and progression, the significance of SAA as a marker of granulomatous inflammation (15) was higher than the significance of matrix metalloproteinases and their tissue inhibitors. It has been documented that SAA induce transcription of MMPs mRNA $(16,17,21)$ suggesting the importance of this molecule in regulating protease/antiprotease system and this was probably the reason why only SAA in multivariate analysis showed significant potential in sarcoidosis prediction.

In conclusion, we found significantly increased levels of MMP-9 and TIMP-1 in sarcoidosis patients. TIMP-1 correlated significantly with inflammatory parameters. MMP-9 and TIMP-1 had the potential to predict sarcoidosis, but only SAA retained this ability in multivariate analysis.

\section{Acknowledgements}

This work was financially supported by the Ministry of Education, Science and Technological Development, Republic of Serbia (Project number 175035).

\section{References}

1. Docherty AJP, Murphy G. The tissue metalloproteinase family and the inhibitor TIMP. a study using cDNAs a recombinant proteins. Ann Rheum Dis 1990; 49: 469-79.

2. Elkington PTG, Friedland JS. Matrix metalloproteinases in destructive pulmonary pathology. Thorax 2006; 61: 259-266

3. Brew K, Dinakarpandian D, Nagase H. Tissue inhibitors of metalloproteinases: evolution, structure and function. Biochim Biophys Acta 2000; 1477: 267-83

4. Henry MT, McMahon K, Mackarel AJ et al. Matrix metalloproteinases and tissue inhibitor of metalloproteinase-1 in sarcoidosis and IPF. Eur Respir J 2002;20:1220-7 
5. Fireman E, Kraiem Z, Sade $O$ et al. Induced sputum-retrieved matrix metalloproteinase 9 and tissue metalloproteinase inhibitor 1 in granulomatous diseases. Clin Exp Immunol 2002;130:331-7

6. Shimada A, Koga T, Oshita Y, Hanada M, Nagafuchi Y, Aizawa H. Reduced pulmonary function is associated with enhanced inflammation and tissue inhibitor of metalloproteinase 1 concentration in the bronchoalveolar lavage fluid of patients with lung parenchymal sarcoidosis. Kurume Med J 2008; 55: 13-17

7. Gonzalez AA, Segura AM, Horiba K et al. Matrix metalloproteinases and their tissue inhibitors in the lesions of cardiac and pulmonary sarcoidosis: an immunohistochemical study. Hum Pathol 2002;33:1158-64.

8. Simpson JL, Scott RJ, Boyle MJ, Gibson PG. Differential proteolytic enzyme activity in eosinophilic and neutrophilic asthma. Am J Respir Crit Care Med 2005; 172: 559-565

9. Stanojkovic I, Kotur Stevuljevic J, Spasic S, Milenkovic B, Vujic T, Stefanovic A, Ivanisevic J. Relationship between bone resorption, oxidative stress and inflammation in severe COPD exacerbation. Clin Biochem 2013; 46: 1678-1682

10. The Joint Statement of the American Thoracic Society (ATS), the European Respiratory Society (ERS) and the World Association of Sarcoidosis and Other Granulomatous Disorders (WASOG). Statement on Sarcoidosis. Am J RespirCrit Care Med 1999; 160: 736-755

11. Rothkrantz-Kos S, Van Dieijen-Visser MP, Mulder PGH, Drent M. Agusti A. Potential usefulness of inflammatory markers to monitor respiratory function impairment in sarcoidosis. Clin Chem 2003; 49: 1510-1517

12. Miyoshi S, Hamad H, Kadowaki T, Hamaguchi N, Ito R, Irifune K et al. Comparative evaluation of serum markers in pulmonary sarcoidosis. Chest 2010; 137: 1391-1397

13. Salazar A, Pinto X, Mana J. Serum amyloid A and high-density lipoprotein cholesterol: serum markers of inflammation in sarcoidosis and other systemic disorders. Eur J Clin Invest 2001; 31: 1070-1077

14. Bargagli E, Magi B, Olivieri C, Bianchi N, Landi C, Rottoli P. Analysis of serum amyloid A in sarcoidosis patients. Resp Med 2011; 105: 775-780

15. Chen ES, Song Z, Willett MH, Heine S, Yung RC, Liu MC et al. Serum amyloid A regulates granulomatous inflammation in sarcoidosis through Toll-like receptor-2. Am J Resp Crit Care Med 2010; 181: 360-373

16. Migita K, Kawabe Y, Tominaga M, Origuchi T, Aoyagi T, Eguchi K. Serum amyloid A protein induces production of matrix metalloproteinases by human synovial fibroblasts. Lab Invest 1998;78: 535-9.

17. Vallon R, Freuler F, Desta-Tsedu N, Robeva A, Dawson J, Wenner P, et al. Serum amyloid A (apoSAA) expression is up-regulated in rheumatoid arthritis and induces transcription ofmatrix metalloproteinases. J Immunol 2001; 166:2801-7.

18. Choi KH, Lee HB, Jeong MY, Rhee YK, Chung MJ et al. The role of matrix-metalloproteinase 9 and tissue inhibitor of metalloproteinase 1 in cryptogenic organizing pneumonia. Chest 2002; 121 : $1478-1485$ 
19. Selman M, Ruiz V, Cabrera S, Segura L, Ramirez R et al. TIMP-1, -2, -3 and -4 in idiopathic pulmonary fibrosis. A prevailing nondegradative lung microenvironment? Am J Physiol Lung Cell Mol Physiol 2000; 279: L562-L574

20. Piotrowski WJ, Nawrocka-Kunecka A, Antczak A, Marczak J, Biernacki R, Kordek P, Kurmanowska Z, Gorski P. Metalloproteianses MMP-9, MMP-2 and their tissue inhibitors TIMP1, TIMP-2 in peripheral transbronchial lung biopsies of patients with sarcoidosis. Pol Arch Med Vewn 2009; 119: 628-635

21. O'Hara R, Murphy EP, Whitehead AS, FitzGerald O, Bresnihan B. Local expression of the serum amyloid A and formyl peptide receptor-like 1 genes in synovial tissue is associated with matrix metalloproteinase production in patients with inflammatory arthritis. Arthr Rheum 2004; 50: 17881799 


\title{
Matriks metaloproteinaze -9 i tkivni inhibitori matriks metaloproteinaza - 1 kod pacijenata sa sarkoidozom
}

\author{
Jasmina Ivanišević ${ }^{*}$, Aleksandra Stefanović ${ }^{1}$, \\ Jelena Kotur Stevuljević ${ }^{1}$, Zorana Jelić Ivanović ${ }^{1}$, Slavica Spasić ${ }^{1}$, \\ Jelica Videnović Ivanov ${ }^{2}$, Violeta Vučinić Mihailovićc ${ }^{2}$
}

${ }^{1}$ Univerzitet u Beogradu - Farmaceutski fakultet, Katedra za medicinsku biohemiju, Vojvode Stepe 450, 11221 Beograd, Srbija

${ }^{2}$ Klinika za plućne bolesti, Klinički centar Srbije, Koste Todorovića 26,

11129 Beograd, Srbija

\section{Kratak sadržaj}

Matriks metaloproteinaze (MMP) i tkivni inhibitori matriks metaloproteinaza (TIMP) imaju značajnu ulogu u destrukciji plućnog ekstracelularnog matriksa. Sarkoidoza je inflamatorno oboljenje koje zahvata različite organe. Utvrđeno je da su koncentracije MMP-9 i TIMP-1 povećane u bronhoalveolarnom lavatu i sputumu pacijenata sa sarkoidozom. Cilj naše studije je bio da se odrede koncentracije MMP-9, TIMP-1 i MMP-9/TIMP-1 kompleksa, MMP9/TIMP-1 odnosa u sarkoidozi, njihova povezanost sa parametrima inflamacije, kao i njihov potencijal za predviđanje postojanja bolesti. Ispitivanjem su obuhvaćeni 101 pacijent sa sarkoidozom i 50 zdravih ispitanika. Analizirani su uzorci seruma. Pored rutinskih biohemijskih parametara, merene su koncentracije visoko-osetljivog C-reaktivnog proteina (hsCRP), serumskog amiloida A (SAA), MMP-9, TIMP-1 i MMP-9/TIMP-1 kompleksa. MMP-9 $(\mathrm{P}<0,05)$, hsCRP, SAA i TIMP-1 $(\mathrm{P}<0,001)$ su bili značajno veći kod pacijenata dok je koncentracija MMP-9/TIMP-1 kompleksa bila veća, ali sa graničnom značajnošću. U sarkoidozi, TIMP-1 je značajno pozitivno korelirao sa inflamatornim parametrima $(\mathrm{P}<0,05)$. Uni-varijantna analiza je pokazala da su MMP-9, TIMP-1, hsCRP i SAA imali značajan potencijal za predviđanje postojanja bolesti. U modelu koji je sadržao MMP-9, TIMP-1, hsCRP i SAA, samo SAA je ostao značajan u ovom predviđanju $(\mathrm{P}<0,01)$. Rezultati pokazuju značaj MMP-9 i TIMP-1 u sarkoidozi.

Ključne reči: sarkoidoza; matriks metaloproteinaza-9;

tkivni inhibitor matriks metaloproteinaza-1; inflamacija 